\title{
Elucidation of the Collision Induced Dissociation Pathways of Water and Alcohol Coordinated Complexes Containing the Uranyl Cation
}

\author{
Michael Van Stipdonk, Victor Anbalagan, and Winnie Chien \\ Department of Chemistry, Wichita State University, Wichita, Kansas, USA \\ Garold Gresham and Gary Groenewold \\ Idaho National Engineering and Environmental Laboratory, Idaho Falls, Idaho, USA \\ Dorothy Hanna \\ Department of Chemistry, Kansas Wesleyan University, Salina, Kansas, USA
}

\begin{abstract}
Multiple-stage tandem mass spectrometry was used to characterize the dissociation pathways for complexes composed of (1) the uranyl ion, (2) nitrate or hydroxide, and (3) water or alcohol. The complex ions were derived from electrospray ionization (ESI) of solutions of uranyl nitrate in $\mathrm{H}_{2} \mathrm{O}$ or mixtures of $\mathrm{H}_{2} \mathrm{O}$ and alcohol. In general, collisional induced dissociation (CID) of the uranyl complexes resulted in elimination of coordinating water and alcohol ligands. For undercoordinated complexes containing nitrate and one or two coordinating alcohol molecules, the elimination of nitric acid was observed, leaving an ion pair composed of the uranyl cation and an alkoxide. For complexes with coordinating water molecules, $\mathrm{MS}^{\mathrm{n}}$ led to the generation of either $\left[\mathrm{UO}_{2}^{2+} \mathrm{OH}^{-}\right]$or $\left[\mathrm{UO}_{2}^{2+} \mathrm{NO}_{3}^{-}\right]$. Subsequent $\mathrm{CID}$ of $\left[\mathrm{UO}_{2}^{2+} \mathrm{OH}^{-}\right]$produced $\mathrm{UO}_{2}^{+}$. The base peak in the spectrum generated by the dissociation of $\left[\mathrm{UO}_{2}^{2+} \mathrm{NO}_{3}^{-}\right]$, however, was an $\mathrm{H}_{2} \mathrm{O}$ adduct to $\mathrm{UO}_{2}^{+}$. The abundance of the species was greater than expected based on previous experimental measurements of the (slow) hydration rate for $\mathrm{UO}_{2}^{+}$when stored in the ion trap. To account for the production of the hydrated product, a reductive elimination reaction involving reactive collisions with water in the ion trap is proposed. (J Am Soc Mass Spectrom 2003, 14, 1205-1214) @ 2003 American Society for Mass Spectrometry
\end{abstract}

$\mathrm{T}$ The speciation and reactivity of uranium is a topic of sustained interest because species-dependent chemistry [1] controls processes ranging from nuclear fuel processing [2] to mobility and fate in the geologic subsurface $[3,4]$. The solution chemistry of uranium is dominated by the uranyl dication, $\mathrm{UO}_{2}^{2+}$, which is known to form complexes with a range of ligands [1]. Specific interaction with solvent will significantly influence the physico-chemical behavior of the uranyl ion and its complexes, and this has motivated investigations of complex composition and stability using infrared spectroscopy and extended X-ray absorption fine structure [5-11]. Unfortunately, explicit control over the interactions of solvent and nonsolvent ligands with the uranyl ion is difficult, which

Published online August 30, 2003

Address reprint requests to Dr. M. J. Van Stipdonk, Department of Chemistrty, Wichita State University, Wichita, KS 67260-0051 or Dr. Gary Groenewold, Idaho National Engineering and Environmental Laboratory, Idaho Falls, ID 83415-2208, USA. E-mail: mike.vanstipdonk@wichita.edu makes the study of species-dependent uranium behavior complicated. To gain a better understanding of the intrinsic interactions between different uranyl species and solvent, we have begun an investigation of uranyl-anion complexes in the gas phase using ion-trap mass spectrometry (IT-MS). Several recent reports have demonstrated that intrinsic metal and metal complex chemistry can be investigated by the (controlled) addition of reagent gas to an ion trap [12-22], or by way of the presence of $\mathrm{H}_{2} \mathrm{O}$ and other small molecule contaminants within the $\mathrm{He}$ bath gas used to collisionally cool ions and improve trapping efficiency [23-25]. The reactions of uranium ions in the gas phase have been the subject of several earlier investigations. Studies by Gibson [26-29], and by Schwarz and coworkers [30] have probed the reactions between $\mathrm{U}^{+}$and $\mathrm{UO}^{+}$and organic compounds such as alkanes and alcohols. Armentrout and Beauchamp [31] investigated the oxidation of $\mathrm{U}^{+}$ using small molecules such as $\mathrm{O}_{2}, \mathrm{CO}, \mathrm{CO}_{2}, \mathrm{COS}$, and 
$\mathrm{D}_{2} \mathrm{O}$. Subsequent studies by Duckworth and coworkers [32], Schwarz and coworkers [33], and Gibson [34] also demonstrated the tendency for oxidation of $\mathrm{U}^{+}$ using small molecules.

The early studies emphasized reactivity of $U$ cations in low oxidation states. However, uranium in the environment occupies higher oxidation states, principally IV and VI. Complex ions containing $\mathrm{U}$ in the higher states can be generated using ESI, and the method has been used in prior investigations to generate the gasphase uranyl ion for analysis by mass spectrometry and ion mobility-mass spectrometry [35-38]. Combining ESI with an IT-MS would enable investigation of intrinsic reactivity of individual $U$ species. Because gas-phase speciation can be complex, the CID and tandem mass spectrometry capabilities of the IT-MS are invaluable for elucidating the composition and structure of gasphase ions. Presented here is a study in which ESI was used to produce gas-phase ions from solutions containing uranyl nitrate in solvent systems ranging from pure $\mathrm{H}_{2} \mathrm{O}$ to mixtures of $\mathrm{H}_{2} \mathrm{O}$ and alcohol. Multiple-stage tandem mass spectrometry was then used to determine the CID pathways for the various complex ions generated. These fundamental studies identify the analytical behavior of uranyl under ESI conditions, and establish the ground work for the analytical and intrinsic studies of more complex uranyl-bearing uranyl systems. The behavior is important for analyte recognition, which is key to understanding geochemical transport and solubilization behavior.

\section{Experimental}

Uranyl nitrate hexahydrate, $\mathrm{UO}_{2}\left(\mathrm{NO}_{3}\right)_{2} \cdot 6 \mathrm{H}_{2} \mathrm{O}$ was purchased from Fluka/Sigma-Aldrich (St. Louis, MO) and used as received. Methanol $(\mathrm{MeOH})$, ethanol $(\mathrm{EtOH})$, 1,1- $d_{2}$ ethyl alcohol $\left(d_{2} \mathrm{EtOH}\right), 2,2,2-d_{3}$ ethyl alcohol $\left(d_{3} \mathrm{EtOH}\right)$, ethyl- $d_{5}$ alcohol $\left(d_{5} \mathrm{EtOH}\right)$ and $n$-propanol $(n-\mathrm{PrOH})$ were purchased from Aldrich Chemical (St. Louis, MO) and used as received. A stock solution $(1 \times$ $\left.10^{-3} \mathrm{M}\right)$ of $\mathrm{UO}_{2}\left(\mathrm{NO}_{3}\right)_{2} \cdot 6 \mathrm{H}_{2} \mathrm{O}$ was prepared by dissolving the appropriate amount of solid material in deionized $\mathrm{H}_{2} \mathrm{O}$.

ESI mass spectra were collected using a Finnigan LCQ-Deca ion-trap mass spectrometer (ThermoFinnigan Corporation, San Jose, CA). The uranyl nitrate stock solution and water:alcohol solutions were infused into the ESI-MS instrument using the incorporated syringe pump at a flow rate of $3-5 \mu \mathrm{l} / \mathrm{min}$. The atmospheric pressure ionization stack settings for the LCQ (lens voltages, quadrupole and octapole voltage offsets, etc.) were optimized for maximum ion transmission to the ion trap mass analyzer by using the auto-tune routine within the LCQ Tune program. Following the instrument tune, the spray needle voltage was maintained at $+5 \mathrm{kV}$ and the $\mathrm{N}_{2}$ sheath gas flow at 25 units (arbitrary to the LCQ instrument, corresponding to approximately .375 liters $/ \mathrm{min}$ ). To ensure maximum yield of solvated uranyl cation complexes, the capillary (desolvation)
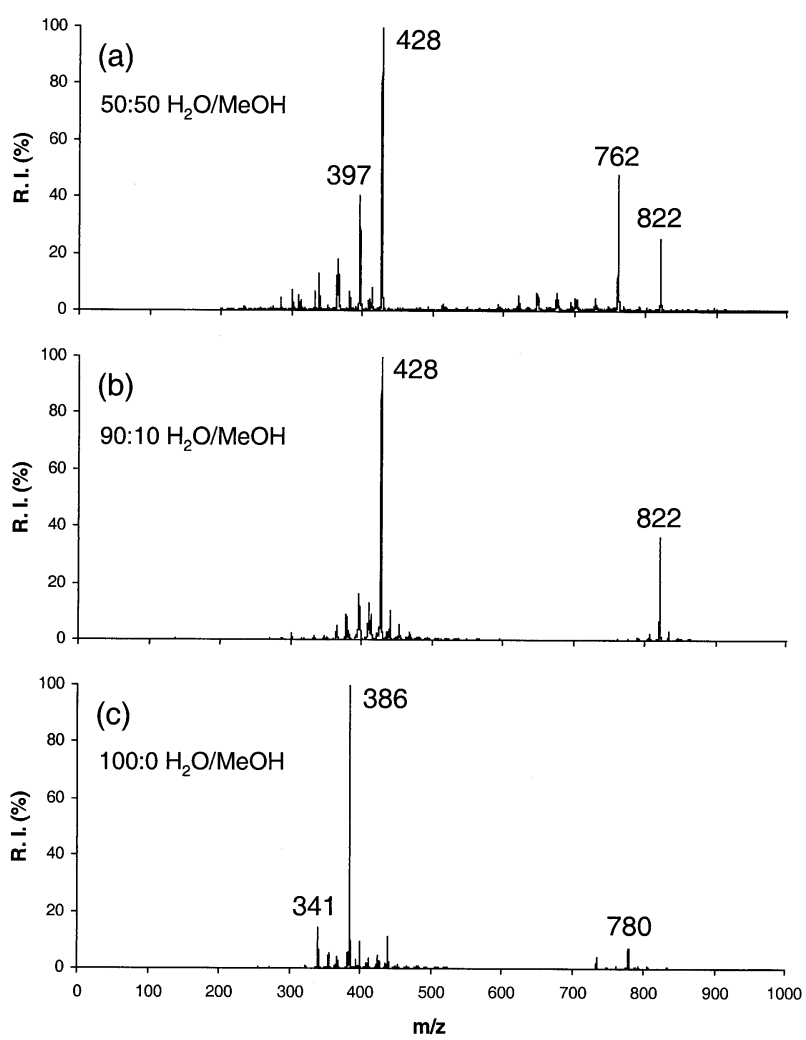

Figure 1. ESI mass spectra generated from $\mathrm{UO}_{2}\left(\mathrm{NO}_{3}\right)_{2}$ dissolved in (a) $50: 50 \mathrm{MeOH} / \mathrm{H}_{2} \mathrm{O}$, (b) $90: 10 \mathrm{MeOH} / \mathrm{H}_{2} \mathrm{O}$, and (c) deionized $\mathrm{H}_{2} \mathrm{O} . \mathrm{UO}_{2}\left(\mathrm{NO}_{3}\right)_{2}$ concentration in each case was $1 \mathrm{mM}$, capillary desolvation temperature $115^{\circ} \mathrm{C}$.

temperature was maintained between $110^{\circ} \mathrm{C}$ and $130^{\circ} \mathrm{C}$. The ion trap analyzer was operated at a pressure of $\sim 1.5 \times 10^{-5}$ torr. Helium gas, admitted directly into the ion trap, was used as the bath/buffer gas to improve trapping efficiency and as the collision gas for CID experiments.

CID experiments were performed by setting the isolation width between 5 and $12 \mathrm{u}$ (depending on the species), the activation $Q$ (as labeled by instrument manufacturer, used to adjust the $q$ value for the resonant excitation of the precursor ion during the CID portion of the experiment) at .3 and the activation amplitude at $10-20 \%$ (of $5 \mathrm{~V}$ ). In all cases, activation times for CID were $30 \mathrm{~ms}$.

\section{Results and Discussion}

Our initial experiments involved the generation of ESI spectra from solutions containing uranyl nitrate in solvent mixtures containing different relative proportions of $\mathrm{H}_{2} \mathrm{O}$ and $\mathrm{MeOH}$. These trials were undertaken to assess the influence of the composition of the solvent system on the production of ion signal by ESI, and to qualitatively probe the preference of the uranyl cation to be coordinated by $\mathrm{H}_{2} \mathrm{O}$ or $\mathrm{MeOH}$ within gas-phase complexes. Figure 1 shows the ESI mass spectra generated from $\mathrm{UO}_{2}\left(\mathrm{NO}_{3}\right)_{2}$ dissolved in 50:50 $\mathrm{MeOH} / \mathrm{H}_{2} \mathrm{O}$ 
(Figure 1a), 90:10 $\mathrm{H}_{2} \mathrm{O} / \mathrm{MeOH}$ (Figure 1b), and pure deionized $\mathrm{H}_{2} \mathrm{O}$ (Figure 1c). The dominant species observed in the mass spectra derived from the mixed $\mathrm{MeOH} /$ water solvent systems was one at mass to charge ratio $(m / z) 428$, consistent with a composition that included a single $\mathrm{UO}_{2}^{2+}$ cation, one nitrate anion and three coordinating $\mathrm{MeOH}$ molecules $\left[\mathrm{UO}_{2}^{2+}\left(\mathrm{NO}_{3}^{-}\right)(\mathrm{MeOH})_{3}\right]$. An analogous species, with $\mathrm{MeOH}$ replaced by $\mathrm{H}_{2} \mathrm{O}$, was observed at $m / z 386$ in the spectrum of uranyl nitrate dissolved in deionized $\mathrm{H}_{2} \mathrm{O}$, $\left[\mathrm{UO}_{2}^{2+}\left(\mathrm{NO}_{3}^{-}\right)\left(\mathrm{H}_{2} \mathrm{O}\right)_{3}\right]$. This spectrum also contained a less abundant ion at $\mathrm{m} / \mathrm{z} 341$ in which nitrate was replaced by hydroxide, $\left[\mathrm{UO}_{2}^{2+}\left(\mathrm{OH}^{-}\right)\left(\mathrm{H}_{2} \mathrm{O}\right)_{3}\right]$. In the ESI spectrum produced from the sample with high $\mathrm{MeOH}$ content, a prominent peak was observed at $\mathrm{m} / \mathrm{z} 397$, consistent with the formation of a complex with composition including $\mathrm{UO}_{2}^{2+}, \mathrm{MeO}^{-}$, and three coordinating $\mathrm{MeOH}$ molecules, $\left[\mathrm{UO}_{2}^{2+}\left(\mathrm{MeO}^{-}\right)(\mathrm{MeOH})_{3}\right]$. Also present within the low mass region of the spectrum were complex ions containing $\mathrm{UO}_{2}^{2+}$, either nitrate or $\mathrm{MeO}^{-}$, and 1 or 2 coordinating $\mathrm{H}_{2} \mathrm{O}$ or $\mathrm{MeOH}$ molecules.

Larger polyatomic species were observed at $\mathrm{m} / \mathrm{z} 822$ in Figure 1a and at $\mathrm{m} / \mathrm{z} 780$ in Figure 1c, and are consistent with the addition of an $\mathrm{UO}_{2}\left(\mathrm{NO}_{3}\right)_{2}$ unit to the species at 428 and 386 , respectively. In the spectrum shown in $1 \mathrm{a}$, a third prominent peak was observed at $\mathrm{m} / \mathrm{z} \sim 762$. This peak was unusually wide, with pronounced tailing to the low mass side and a significant chemical mass shift $[39,40]$. These observations are consistent with the formation of a weakly bound complex. Attempts to isolate the species for a higher resolution scan, and thus better determine the $\mathrm{m} / \mathrm{z}$ value were not successful, presumably because of the instability of the complex. Several compositions are possible for this mass assignment, and identification remains tentative. Additionally, large polyatomic ions (not shown in Figure 1) were observed at $m / z 1095,1156,1457$, and 1851. These ions have tentative compositions consistent with $\left[\left(\mathrm{UO}_{2}\right)_{3}\left(\mathrm{NO}_{3}\right)(\mathrm{MeO})(\mathrm{MeOH})_{6}\right]^{+}, \quad\left[\left(\mathrm{UO}_{2}\right)_{3}\left(\mathrm{NO}_{3}\right)_{3}\right.$ $\left.(\mathrm{MeOH})_{5}\right]^{+}, \quad\left[\left(\mathrm{UO}_{2}\right)_{4}\left(\mathrm{NO}_{3}\right)_{3}(\mathrm{MeO})(\mathrm{MeOH})_{5}\right]^{+}, \quad$ and $\left[\left(\mathrm{UO}_{2}\right)_{5}\left(\mathrm{NO}_{3}\right)_{5}(\mathrm{MeO})(\mathrm{MeOH})_{5}\right]^{+}$.

For the $\mathrm{H}_{2} \mathrm{O} / \mathrm{MeOH}$ mixed solvent system, the peaks at $\mathrm{m} / \mathrm{z} 428$ and 822 remained the predominant ions observed when the relative proportion of alcohol was reduced to $5 \%$. The persistence of the $\mathrm{MeOH}$-solvated complex ions suggests that $\mathrm{UO}_{2}^{2+}$ has a higher affinity for alcohol molecules than for $\mathrm{H}_{2} \mathrm{O}$, which is consistent with the tendency for the former to be stronger electron donors to metal ions [41]. In general, the greatest influence of decreasing $\mathrm{MeOH}$ content in the spray solvent system was an observed decrease in intensity of the peak at $\sim m / z 762$, and analogous species observed when using the other alcohols.

Proposed compositions for the major species generated by ESI of uranyl nitrate dissolved in 50:50 ROH/ $\mathrm{H}_{2} \mathrm{O}(\mathrm{ROH}=$ methanol, ethanol, and $n$-propanol $)$ are provided in Table 1. In most cases, the assigned compositions were supported by MS $^{\mathrm{n}}$ CID except for those
Table 1. Compositions of prominent ions observed in the ESI mass spectra of uranyl nitrate sprayed from alcohol/water solutions

\begin{tabular}{|c|c|c|}
\hline Alcohol & $m / z$ & Composition \\
\hline \multirow[t]{8}{*}{ Methanol } & 333 & {$\left[\mathrm{UO}_{2}^{2+}\left(\mathrm{MeO}^{-}(\mathrm{MeOH})\right]\right.$} \\
\hline & 365 & {$\left[\mathrm{UO}_{2}^{2+}\left(\mathrm{MeO}^{-}(\mathrm{MeOH})_{2}\right]\right.$} \\
\hline & 397 & {$\left[\mathrm{UO}_{2}^{2+}\left(\mathrm{MeO}^{-}(\mathrm{MeOH})_{3}\right]\right.$} \\
\hline & 364 & {$\left[\mathrm{UO}_{2}^{2+}\left(\mathrm{NO}_{3}^{-}(\mathrm{MeOH})\right]\right.$} \\
\hline & 396 & {$\left[\mathrm{UO}_{2}^{2+}\left(\mathrm{NO}_{3}^{-}(\mathrm{MeOH})_{2}\right]\right.$} \\
\hline & 428 & {$\left[\mathrm{UO}_{2}^{2+}\left(\mathrm{NO}_{3}^{-}(\mathrm{MeOH})_{3}\right]\right.$} \\
\hline & 762 & Unidentified \\
\hline & 822 & $\left.\left[\mathrm{UO}_{2}^{2+}\right)_{2}\left(\mathrm{NO}_{3}^{-}\right)_{3}(\mathrm{MeOH})_{3}\right]$ \\
\hline \multirow[t]{7}{*}{ Ethanol } & 361 & {$\left[\mathrm{UO}_{2}^{2+}\left(\mathrm{EtO}^{-}\right)(\mathrm{EtOH})\right]$} \\
\hline & 407 & {$\left[\mathrm{UO}_{2}^{2+}\left(\mathrm{EtO}^{-}\right)(\mathrm{EtOH})_{2}\right]$} \\
\hline & 452 & {$\left[\mathrm{UO}_{2}^{2+}\left(\mathrm{EtO}^{-}\right)(\mathrm{EtOH})_{3}\right]$} \\
\hline & 378 & {$\left[\mathrm{UO}_{2}^{2+}\left(\mathrm{NO}_{3}{ }^{-}\right)(\mathrm{EtOH})\right]$} \\
\hline & 424 & {$\left[\mathrm{UO}_{2}^{2+}\left(\mathrm{NO}_{3}^{-}\right)(\mathrm{EtOH})_{2}\right]$} \\
\hline & 470 & {$\left[\mathrm{UO}_{2}^{2+}\left(\mathrm{NO}_{3}^{-}\right)(\mathrm{EtOH})_{3}\right]$} \\
\hline & 864 & $\left.\left[\mathrm{UO}_{2}^{2+}\right)_{2}\left(\mathrm{NO}_{3}^{-}\right)_{3}(\mathrm{EtOH})_{3}\right]$ \\
\hline \multirow[t]{7}{*}{$n$-Propanol } & 369 & {$\left[\mathrm{UO}_{2}^{2+}\left(n \mathrm{PrO}^{-}\right)(n \mathrm{PrOH})\right]$} \\
\hline & 449 & {$\left[\mathrm{UO}_{2}^{2+}\left(n \mathrm{PrO}^{-}\right)(n \mathrm{PrOH})_{2}\right]$} \\
\hline & 509 & {$\left[\mathrm{UO}_{2}^{2+}\left(n \mathrm{PrO}^{-}\right)(n \mathrm{PrOH})_{3}\right]$} \\
\hline & 393 & $\left.\left[\mathrm{UO}_{2}^{2+}\left(\mathrm{NO}_{2}^{-}\right) n \mathrm{PrOH}\right)\right]$ \\
\hline & 452 & $\left.\left[\mathrm{UO}_{2}^{2+}\left(\mathrm{NO}_{2}^{-}\right) n \mathrm{PrOH}\right)_{2}\right]$ \\
\hline & 512 & $\left.\left[\mathrm{UO}_{2}^{2+}\left(\mathrm{NO}_{2}^{-}\right) n \mathrm{PrOH}\right)_{3}\right]$ \\
\hline & 906 & {$\left[\left(\mathrm{UO}_{2}^{2+}\right)_{2}\left(\mathrm{NO}_{3}^{-}\right)_{3}(n \mathrm{PrOH})_{3}\right]$} \\
\hline \multirow[t]{7}{*}{ No alcohol } & 305 & {$\left[\mathrm{UO}_{2}^{2+}\left(\mathrm{OH}^{-}\right)\left(\mathrm{H}_{2} \mathrm{O}\right)\right]$} \\
\hline & 323 & {$\left[\mathrm{UO}_{2}^{2+}\left(\mathrm{OH}^{-}\right)\left(\mathrm{H}_{2} \mathrm{O}\right)_{2}\right]$} \\
\hline & 341 & {$\left[\mathrm{UO}_{2}^{2+}\left(\mathrm{OH}^{-}\right)\left(\mathrm{H}_{2} \mathrm{O}\right)_{3}\right]$} \\
\hline & 350 & {$\left[\mathrm{UO}_{2}^{2+}\left(\mathrm{NO}_{3}{ }^{-}\right)\left(\mathrm{H}_{2} \mathrm{O}\right)\right]$} \\
\hline & 368 & {$\left[\mathrm{UO}_{2}^{2+}\left(\mathrm{NO}_{3}{ }^{-}\right)\left(\mathrm{H}_{2} \mathrm{O}\right)_{2}\right]$} \\
\hline & 386 & {$\left[\mathrm{UO}_{2}^{2+}\left(\mathrm{NO}_{3}^{-}\right)\left(\mathrm{H}_{2} \mathrm{O}\right)_{3}\right]$} \\
\hline & 780 & {$\left[\left(\mathrm{UO}_{2}^{2+}\right)_{2}\left(\mathrm{NO}_{3}^{-}\right)_{3}^{-}\left(\mathrm{H}_{2} \mathrm{O}\right)_{3}\right]$} \\
\hline
\end{tabular}

unstable species that did not survive the ion isolation step required for the dissociation experiment. Trials attempted using solutions containing $n$-butanol were plagued by significant precipitation of solids within the fused silica transport capillary used in the ESI instrument. Therefore, an investigation of butanol coordinated uranyl complexes was not conducted.

Figure 2 shows, as representative examples for the alcohol containing complexes, multiple stage CID spectra initiated with the dissociation of the species at $\mathrm{m} / \mathrm{z}$ $428,\left[\mathrm{UO}_{2}^{2+}\left(\mathrm{NO}_{3}^{-}\right)(\mathrm{MeOH})_{3}\right]^{+}$, generated from ESI of uranyl nitrate in 50:50 MeOH$/ \mathrm{H}_{2} \mathrm{O}$. The dissociation spectra produced at each CID stage were complex, containing both product ions from fragmentation reactions, and $\mathrm{H}_{2} \mathrm{O}$ adducts to those product ions formed by association reactions with adventitious $\mathrm{H}_{2} \mathrm{O}$ present as a contaminant in the He buffer/bath gas $\left(\mathrm{H}_{2} \mathrm{O}\right.$ adducts are identified with an asterisk in figures). In general, the $\mathrm{H}_{2} \mathrm{O}$ adducts can be identified by characteristic peak tails and chemical mass shifts (shifts of $\sim .2-.3 \mathrm{u}$ lower than expected mass). In addition, the adducts were identified in our experiments by isolating expected product ions in the ion trap for periods of 100-300 ms, without an imposed activation amplitude. During the isolation step, all ionized species except the one chosen for storage are resonantly ejected from the ion trap. The appearance of peaks $18 \mathrm{u}$ higher than the isolated ion is 

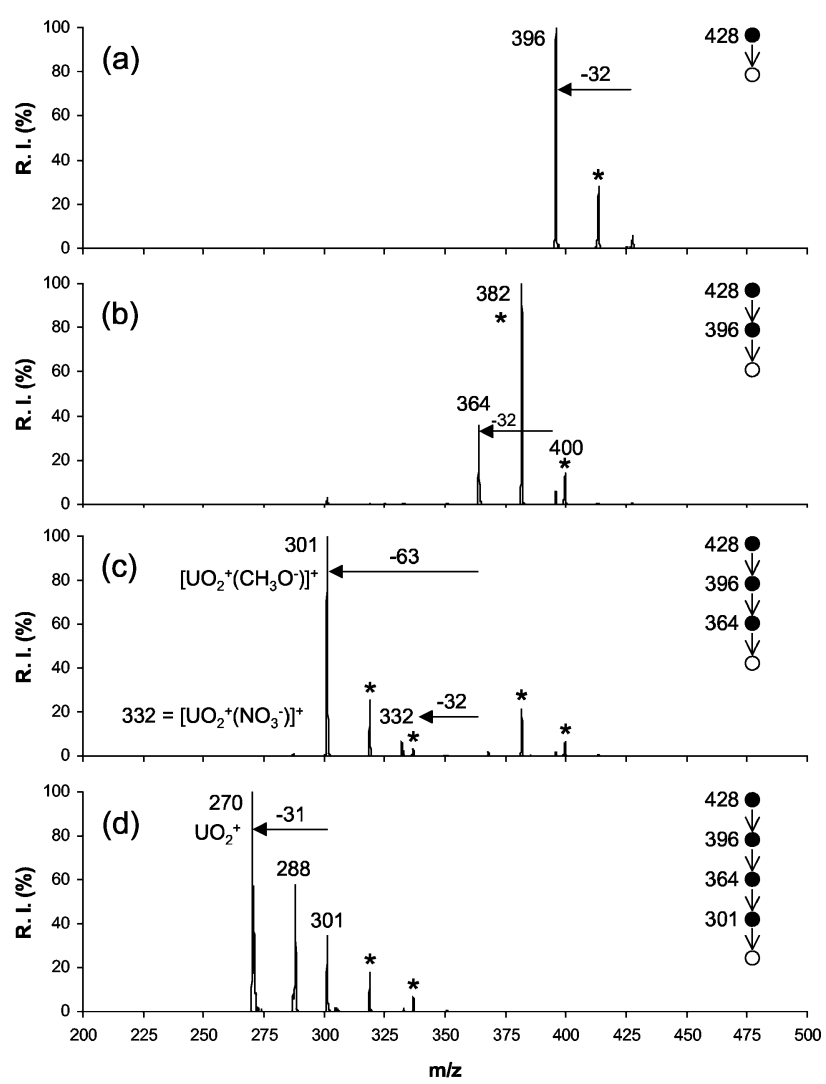

Figure 2. Multiple stage CID spectra initiated with the dissociation of the $\left[\mathrm{UO}_{2}^{2+}\left(\mathrm{NO}_{3}^{-}\right)(\mathrm{MeOH})_{3}\right]^{+}$complex ion derived from $\mathrm{UO}_{2}\left(\mathrm{NO}_{3}\right)_{2}$ dissolved in 50:50 MeOH/ $\mathrm{H}_{2} \mathrm{O}$. Peaks marked with an asterisk indicate $\mathrm{H}_{2} \mathrm{O}$ adducts formed from reaction of the CID products with adventitious water in the IT-MS.

indicative of the formation of $\mathrm{H}_{2} \mathrm{O}$ adducts [23-25]; the abundance of the adducts increased as the isolation and storage time was extended. The formation of abundant $\mathrm{H}_{2} \mathrm{O}$ adducts indicates that several of the uranyl complex ions show a significant tendency to accept ligands via gas-phase association reactions in the ion trap. The reaction kinetics for the addition of one or more $\mathrm{H}_{2} \mathrm{O}$ ligands to $\mathrm{UO}_{2}^{+}$and related species generated by ioninduced sputtering of solid $\mathrm{UO}_{3}$ was recently investigated [42]. While beyond the scope of the present study, the reaction kinetics for the addition of $\mathrm{H}_{2} \mathrm{O}$ ligands to the various CID products generated from the alcohol coordinated complexes containing $\mathrm{UO}_{2}^{2+}$ were also investigated and will be the subject of a separate report [43].

The multiple-stage dissociation pathways for the CID of $m / z 428\left[\mathrm{UO}_{2}^{2+}\left(\mathrm{NO}_{3}^{-}\right)(\mathrm{MeOH})_{3}\right]$ are shown in Scheme 1. CID (MS/MS or MS ${ }^{2}$ ) caused the loss of $32 \mu$, consistent with the elimination of a single $\mathrm{MeOH}$ molecule. Subsequent CID $\left(\mathrm{MS}^{3}\right)$ of $\left[\mathrm{UO}_{2}^{2+}\left(\mathrm{NO}_{3}^{-}\right)(\mathrm{MeOH})_{2}\right]$ at $m / z$ 396, caused the elimination of a second $\mathrm{MeOH}$ molecule to produce $\left[\mathrm{UO}_{2}^{2+}\left(\mathrm{NO}_{3}^{-}\right)(\mathrm{MeOH})\right]$ at $\mathrm{m} / \mathrm{z} 364$. A second minor dissociation pathway involved the loss of $95 \mathrm{u}$, consistent with the elimination of $\mathrm{MeOH}$ and $\mathrm{HNO}_{3}$, to produce an ion at $\mathrm{m} / \mathrm{z}$ 301. CID of the ion at $\mathrm{m} / \mathrm{z} 364\left(\mathrm{MS}^{4}\right)$ primarily caused the elimination of
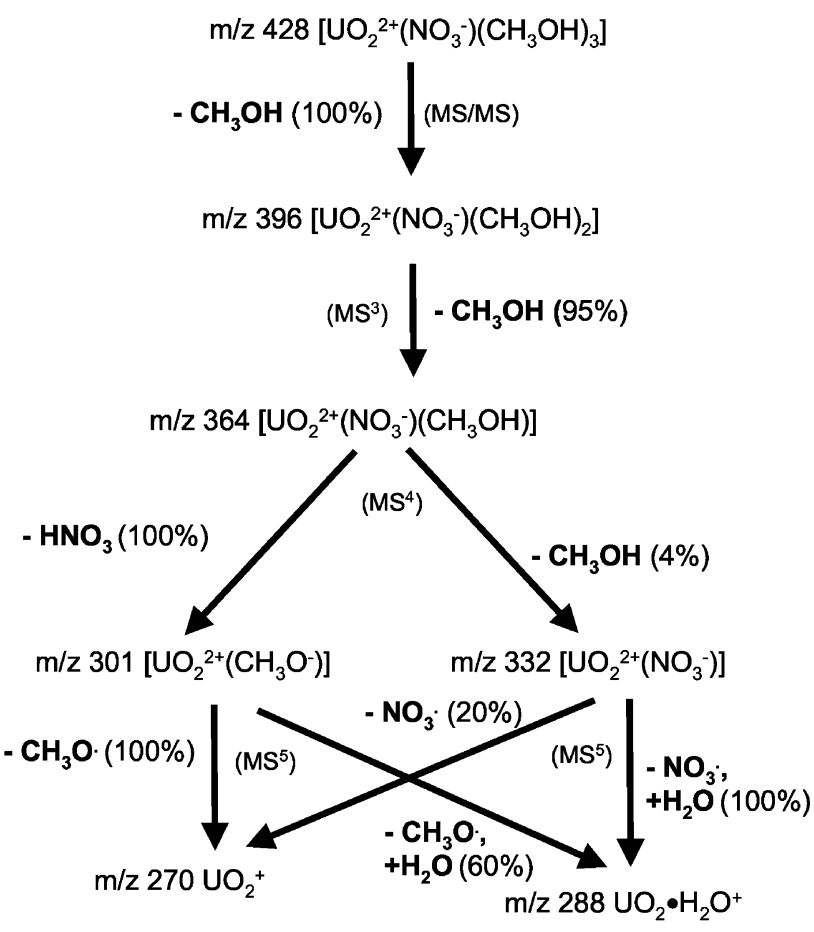

Scheme 1. $\mathrm{MS}^{\mathrm{n}}$ pathways for the dissociation of $\left[\mathrm{UO}_{2}^{2+}\left(\mathrm{NO}_{3}^{-}\right)(\mathrm{MeOH})_{3}\right]^{+}$. Product ion intensities are reported relative to base peak at each CID stage. In some stages, $\mathrm{H}_{2} \mathrm{O}$ adducts to product ions were the base peaks.

$\mathrm{HNO}_{3}$ to generate a product ion at $\mathrm{m} / \mathrm{z}$ 301, with a minor pathway corresponding to the loss of $\mathrm{MeOH}$ to produce $\left[\mathrm{UO}_{2}^{2+}\left(\mathrm{NO}_{3}^{-}\right)\right]$at $\mathrm{m} / \mathrm{z} 332$. The ion at $\mathrm{m} / \mathrm{z} 301$ corresponds to an ion-pair composed of the uranyl cation and a deprotonated $\mathrm{MeOH}$ molecule, $\left[\mathrm{UO}_{2}^{2+}\left(\mathrm{MeO}^{-}\right)\right]$, consistent with previously reported tendencies for lanthanide and actinide species to form alkoxide complexes [44-46].

The $\mathrm{MS}^{\mathrm{n}}$ experiments suggest that the species at $\mathrm{m} / \mathrm{z}$ 428 may have a composition of either $\left[\mathrm{UO}_{2}^{2+}\left(\mathrm{NO}_{3}^{-}\right)\right.$ $\left.(\mathrm{MeOH})_{3}\right]$ or $\left[\mathrm{UO}_{2}^{2+}\left(\mathrm{CH}_{3} \mathrm{O}^{-}\right)\left(\mathrm{HNO}_{3}\right)(\mathrm{MeOH})_{2}\right]$. A significant ion population with the latter composition might be expected to eliminate $\mathrm{HNO}_{3}$ at any CID stage because of a weaker interaction between $\mathrm{HNO}_{3}$ and $\mathrm{UO}_{2}^{2+}$ vis-à-vis $\mathrm{NO}_{3}^{-}$and $\mathrm{UO}_{2}^{2+}$. The preferred elimination of nitric acid at the $\mathrm{MS}^{4}$ stage might instead suggest that the complex ion has the former composition, and that a proton is transferred from a coordinating alcohol molecule to the nitrate anion during the dissociation reaction. Such a proton transfer process is not without precedent, and has been recently reported for gas-phase alcohol complexes incorporating $\mathrm{Pb}^{2+}$ [47]. The strong tendency to form alkoxide species, noted above, may be a driving force for the apparent proton transfer step and subsequent elimination of $\mathrm{HNO}_{3}$.

$\mathrm{CID}$ of $\left[\mathrm{UO}_{2}^{2+}\left(\mathrm{MeO}^{-}\right)\right]$at $\mathrm{m} / \mathrm{z} 301\left(\mathrm{MS}^{5}\right)$ caused the elimination of $31 \mathrm{u}$, presumably via the elimination of a methoxy radical, to generate the reduced uranyl cation, $\mathrm{UO}_{2}^{+}$, at $m / z 270$. A prominent peak at $m / z 288$ was also observed in the product ion spectrum generated at the 

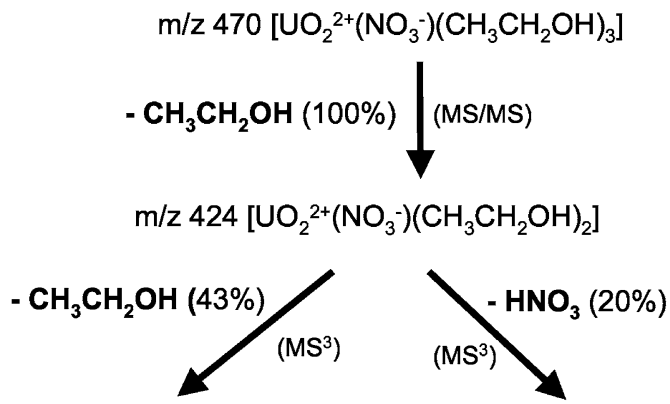

$\mathrm{m} / \mathrm{z} 378\left[\mathrm{UO}_{2}{ }^{2+}\left(\mathrm{NO}_{3}{ }^{-}\right)\left(\mathrm{CH}_{3} \mathrm{CH}_{2} \mathrm{OH}\right)\right]$

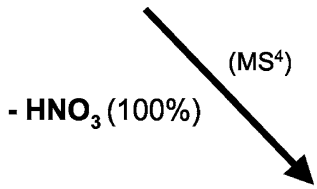

$\mathrm{m} / \mathrm{z} 361\left[\mathrm{UO}_{2}{ }^{2+}\left(\mathrm{CH}_{3} \mathrm{CH}_{2} \mathrm{O}^{-}\right)\left(\mathrm{CH}_{3} \mathrm{CH}_{2} \mathrm{OH}\right)\right]$
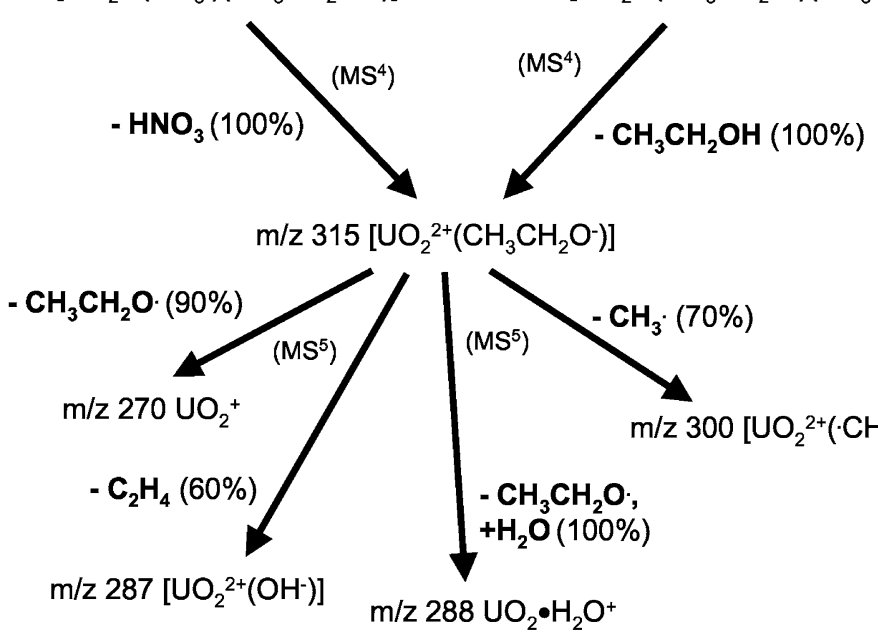

Scheme 2. $\mathrm{MS}^{\mathrm{n}}$ pathways for the dissociation of $\left[\mathrm{UO}_{2}^{2+}\left(\mathrm{NO}_{3}^{-}\right)(\mathrm{EtOH})_{3}\right]^{+}$. Product ion intensities are reported relative to base peak at each CID stage. In some stages, $\mathrm{H}_{2} \mathrm{O}$ adducts to product ions were the base peaks.

$\mathrm{MS}^{5}$ CID stage, suggesting the formation of a hydrated, reduced uranyl ion with formula $\mathrm{UO}_{2}^{+} \cdot \mathrm{H}_{2} \mathrm{O}$. The generation of this species is discussed further in the next section.

The multiple stage dissociation pathways for the species $\left[\mathrm{UO}_{2}^{2+}\left(\mathrm{NO}_{3}^{-}\right)(\mathrm{EtOH})_{3}\right]$ and $\left[\mathrm{UO}_{2}^{2+}\left(\mathrm{NO}_{3}^{-}\right)(n-\right.$ $\mathrm{PrOH})_{3}$ ] are shown in Schemes 2 and 3, respectively. In general, the $\mathrm{MS}^{\mathrm{n}}$ results were similar to those exhibited by $\left[\mathrm{UO}_{2}^{2+}\left(\mathrm{NO}_{3}^{-}\right)(\mathrm{MeOH})_{3}\right]$, including the eventual formation of alkoxide-containing complexes with composition $\left[\mathrm{UO}_{2}^{2+}\left(\mathrm{EtO}^{-}\right)\right]$and $\left[\mathrm{UO}_{2}^{2+}\left(n-\mathrm{PrO}^{-}\right)\right]$at $m / z 315$ and 329 , respectively. One notable difference was the observation of an increased tendency to eliminate $\mathrm{HNO}_{3}$ at an earlier $\left(\mathrm{MS}^{3}\right)$ stage. Based on the relative intensities of product ions as provided in Schemes 2 and 3, the tendency to lose $\mathrm{HNO}_{3}$, relative to the loss of an alcohol molecule, at earlier stages followed the trend $n-\mathrm{PrOH}>$ $\mathrm{EtOH}>\mathrm{MeOH}$. If the loss of $\mathrm{HNO}_{3}$ from the gas-phase complexes involves transfer of a proton from $\mathrm{ROH}$ to the nitrate anion, this trend is consistent with the known acidities of the alcohols in the gas phase [48, 49]: Acidity increases, in general, with the size of the alkyl group.

A second major difference observed for complexes incorporating $\mathrm{EtOH}$ and $n-\mathrm{PrOH}$ was the appearance of fragmentation pathways that appeared to involve cleavage of $\mathrm{C}-\mathrm{C}$ bonds within an alcohol ligand. For example, at the $\mathrm{MS}^{5}$ stage, fragmentation pathways corresponding to the loss of $15 \mathrm{u}\left(\cdot \mathrm{CH}_{3}\right)$ from the complexes containing EtOH and to the loss of 15 and 29 $\mathrm{u}\left(\cdot \mathrm{C}_{2} \mathrm{H}_{5}\right)$ from the complexes containing $n$-PrOH were observed. For the EtOH-containing complex, the mass of the neutral eliminated shifted by three units (loss of $18 \mathrm{u}$ ) when the $d_{3}$ - and $d_{5}$-EtOH were used in the spray solvent. The loss of $15 \mathrm{u}$ was observed, however, when the $d_{2}-\mathrm{EtOH}$ was used. These results indicate that the reaction pathway involves the elimination of an intact methyl group following $\mathrm{C}-\mathrm{C}$ bond cleavage. For the complex containing EtOH, a product ion at $m / z 285$ was also generated by the $\mathrm{CID}\left(\mathrm{MS}^{5}\right)$ of $\left[\mathrm{UO}_{2}^{2+}\left(\mathrm{CH}_{3} \mathrm{CH}_{2} \mathrm{O}^{-}\right]\right.$. CID generated the same product ion when $d_{2}-\mathrm{EtOH}$ $\left(\mathrm{CH}_{3} \mathrm{CD}_{2} \mathrm{OH}\right)$ was used in the spray solvent. The product ion mass shifted, however, to $\mathrm{m} / \mathrm{z} 288$ when $d_{3}$-EtOH $\left(\mathrm{CD}_{3} \mathrm{CH}_{2} \mathrm{OH}\right)$ was used. These observations suggest that the product ion is generated by insertion into the $\mathrm{C}-\mathrm{C}$ bond to form $\left[\mathrm{UO}_{2}-\mathrm{CH}_{3}\right]^{+}(\mathrm{m} / \mathrm{z} 285)$ by the elimination of $\mathrm{CH}_{2} \mathrm{O}$ as a neutral. A similar product ion was not observed following the CID of $\left[\mathrm{UO}_{2}^{2+}\left(n-\mathrm{PrO}^{-}\right]\right.$.

A third difference was the appearance at the $\mathrm{MS}^{5}$ stage of a product ion at $m / z 287$, which corresponds to the formula $\left[\mathrm{UO}_{2}^{2+}\left(\mathrm{OH}^{-}\right)\right]$. Subsequent CID caused the elimination of $17 \mathrm{u}$ to produce $\mathrm{m} / \mathrm{z} 270\left(\mathrm{UO}_{2}^{+}\right)$. The formation of $m / z 287$ from, for example, $\left[\mathrm{UO}_{2}^{2+}\left(\mathrm{EtO}^{-}\right]^{+}\right.$ suggests the transfer of an $\mathrm{H}$ atom from the alkyl group to the oxygen atom, with the elimination of an alkene 

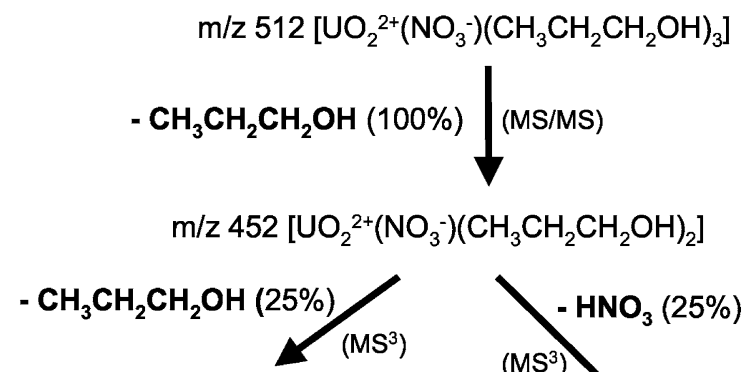

$\mathrm{m} / \mathrm{z} 392\left[\mathrm{UO}_{2}^{2+}\left(\mathrm{NO}_{3}{ }^{-}\right)\left(\mathrm{CH}_{3} \mathrm{CH}_{2} \mathrm{CH}_{2} \mathrm{OH}\right)\right]$
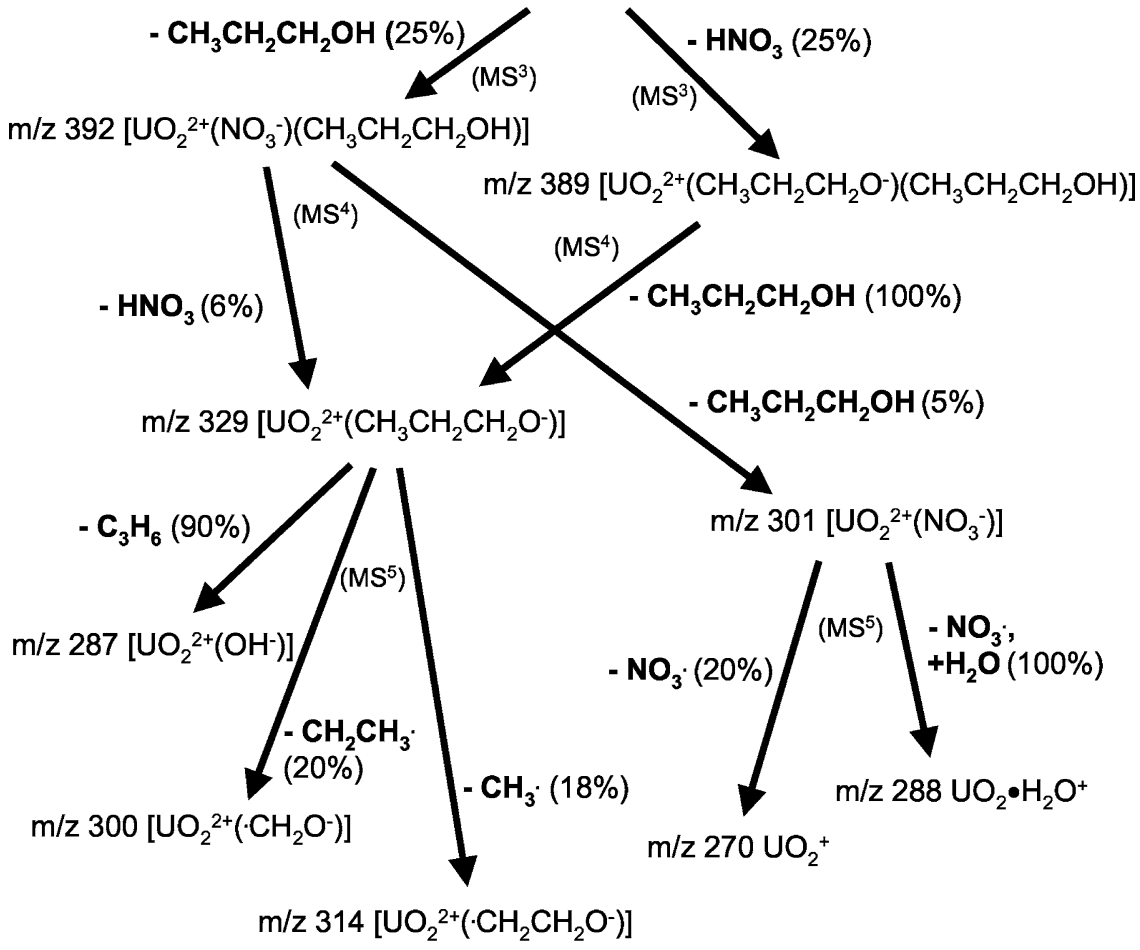

Scheme 3. $\mathrm{MS}^{\mathrm{n}}$ pathways for the dissociation of $\left[\mathrm{UO}_{2}^{2+}\left(\mathrm{NO}_{3}^{-}\right)(n \mathrm{PrOH})_{3}\right]^{+}$. Product ion intensities are reported relative to base peak at each CID stage. In some stages, $\mathrm{H}_{2} \mathrm{O}$ adducts to product ions were the base peaks.

neutral as depicted in Scheme 4. A common observation in previous studies of the reactions between gas-phase $\mathrm{U}^{+}$and alkanes was a tendency toward dehydrogenation [26-30], albeit with the elimination of $\mathrm{H}_{2}$ to form unsaturated neutrals. The product ion at $\mathrm{m} / \mathrm{z} 287$ was also observed when the $d_{2}$-EtOH was used to generate
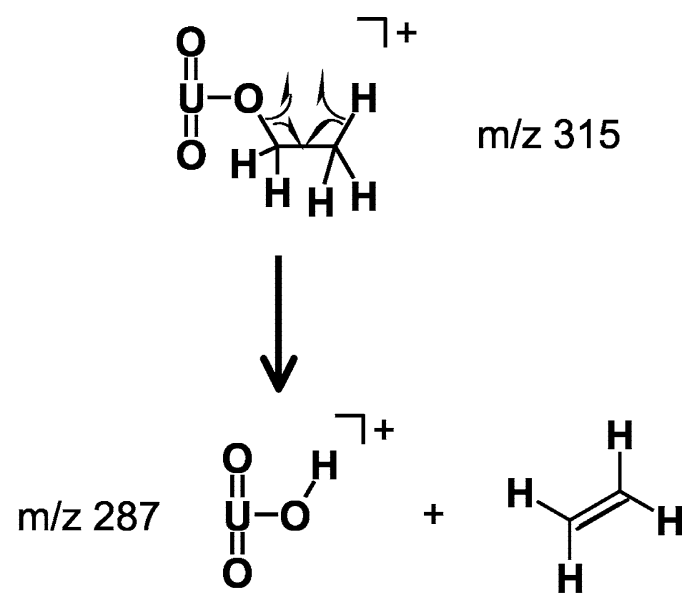

Scheme 4. Proposed reaction to generate $\mathrm{m} / \mathrm{z} 287$ from $\left[\mathrm{UO}_{2}^{2+}\left(\mathrm{EtO}^{-}\right)\right]$. the uranyl complex, but was not observed when the $d_{3}$-EtOH and $d_{5}$-EtOH were used. Transfer from the methyl group of the ethoxy moiety would involve a D atom for the $d_{3}$ - and $d_{5}$-versions of the alcohols, and would shift the mass of the product ion to 288 , which is isobaric with the $\mathrm{H}_{2} \mathrm{O}$ adduct to the $\mathrm{m} / \mathrm{z} 270$ product and the $\left[\mathrm{UO}_{2}-\mathrm{CD}_{3}\right]^{+}$product. However, generation of the $\mathrm{m} / \mathrm{z} 287$ product was the principal pathway observed following CID of $\left[\mathrm{UO}_{2}^{2+}\left(n-\mathrm{PrO}^{-}\right)\right]$, and the pathways to produce $\mathrm{m} / \mathrm{z} 270$ and 288 (the principal reaction products generated from the complex containing methoxide) were not observed. Therefore, this observation, and the trials with $d$-labeled $\mathrm{EtOH}$, support a dissociation pathway involving $\mathrm{H}$-transfer.

An alternative pathway for the formation of the $\mathrm{m} / \mathrm{z}$ 287 product ion from the uranyl-alkoxy precursor ions might involve a reactive collision with an $\mathrm{H}_{2} \mathrm{O}$ molecule within the ion trap via the reaction:

$$
\begin{gathered}
{\left[\mathrm{UO}_{2}^{2+}\left(\mathrm{CH}_{3} \mathrm{CH}_{2} \mathrm{O}^{-}\right)\right]+\mathrm{H}_{2} \mathrm{O} \rightarrow} \\
{\left[\mathrm{UO}_{2}^{2+}\left(\mathrm{CH}_{3} \mathrm{CH}_{2} \mathrm{O}^{-}\right)\left(\mathrm{H}_{2} \mathrm{O}\right)\right]^{*} \rightarrow} \\
{\left[\mathrm{UO}_{2}^{2+}\left(\mathrm{OH}^{-}\right)\right]+\mathrm{CH}_{3} \mathrm{CH}_{2} \mathrm{OH}^{\circ} .}
\end{gathered}
$$


Such a reaction pathway is plausible based on recent experiments that have demonstrated that CID within ion trap instruments involves a significant number of activating collisions between precursor ions and small molecules such as $\mathrm{N}_{2}$ and $\mathrm{H}_{2} \mathrm{O}$ present as contaminants within the He bath gas [50,51]. The reaction shown above would involve the ultimate elimination of $\mathrm{EtOH}$, with a proton extracted from the $\mathrm{H}_{2} \mathrm{O}$ collision partner, and retention of the hydroxyl group by the uranyl ion. Were such a process to occur, with $\mathrm{H}_{2} \mathrm{O}$ in the ion trap as the source of the hydroxyl moiety, one might expect the product at $\mathrm{m} / \mathrm{z} 287$ to be observed following CID of all complexes regardless of the identity of the alkoxy group and the extent of deuterium label (with the caveat that the relative proton affinities of hydroxide and the alkoxides, and the affinity of the uranyl ion for the same species, may play a role in determining the probability of observing this pathway). Therefore, the experimental results described here do not support this mechanism.

As the size of the alcohol increased, so too did the tendency to form a complex containing $\mathrm{UO}_{2}^{2+}$, alkoxide and coordinating alcohol ligands by ESI (Table 1), with general formula $\left[\mathrm{UO}_{2}^{2+}\left(\mathrm{RO}^{-}\right)(\mathrm{ROH})_{3}\right]$. For complex ions derived from $\mathrm{MeOH}$ or $\mathrm{EtOH}$ (Schemes not shown), $\mathrm{MS}^{\mathrm{n}}$ caused successive elimination of alcohol molecules to generate the $\left[\mathrm{UO}_{2}^{2+}\left(\mathrm{RO}^{-}\right)\right]^{+}$. Subsequent CID of $\left[\mathrm{UO}_{2}^{2+}\left(\mathrm{RO}^{-}\right)\right]^{+}$produced spectra qualitatively and quantitatively similar to those reported above. The $\left[\mathrm{UO}_{2}^{2+}\left(n-\mathrm{PrO}^{-}\right)(n-\mathrm{PrOH})_{3}\right]$ complex was sufficiently unstable/labile to prohibit its isolation in the gas phase for CID experiments. It seems reasonable to assume, however, that similar CID behavior would be observed were isolation of the species possible.

The MS ${ }^{\mathrm{n}}$ spectra obtained for the CID of the species at $\mathrm{m} / \mathrm{z}$ 386, $\left[\mathrm{UO}_{2}^{2+}\left(\mathrm{NO}_{3}^{-}\right)\left(\mathrm{H}_{2} \mathrm{O}\right)_{3}\right]$ generated from the aqueous solution of $\mathrm{UO}_{2}\left(\mathrm{NO}_{3}\right)_{2}$ are shown in Figure 3. The MS/MS, $\mathrm{MS}^{3}$, and $\mathrm{MS}^{4}$ CID stages initiated with the ion at $\mathrm{m} / \mathrm{z} 386$ caused the successive elimination of coordinating $\mathrm{H}_{2} \mathrm{O}$ molecules to leave the uranyl-nitrate ion pair, $\left[\mathrm{UO}_{2}^{2+}\left(\mathrm{NO}_{3}^{-}\right)\right]$at $\mathrm{m} / \mathrm{z} 332$. Subsequent $\mathrm{CID}$ of this species produced ions at $\mathrm{m} / \mathrm{z} 270$ and 288. In this case, $m / z 288$ is consistent (based on mass) with the formation of the hydrated, reduced uranyl ion, $\mathrm{UO}_{2}^{+} \cdot \mathrm{H}_{2} \mathrm{O}$. No plausible mechanism to explain the loss of $44 \mathrm{u}$ can be proposed starting from $\left[\mathrm{UO}_{2}^{2+}\left(\mathrm{NO}_{3}^{-}\right)\right]^{+}$ $(\mathrm{m} / \mathrm{z}$ 332). CID of the peak at $\mathrm{m} / \mathrm{z} 288$ (spectrum not shown) caused the elimination of $18 \mu$, consistent with the loss of a $\mathrm{H}_{2} \mathrm{O}$ molecule, forming $\mathrm{UO}_{2}^{+}$at $\mathrm{m} / \mathrm{z} 270$. Figure 4 shows the mass spectrum that was a result of the isolation and storage of $\mathrm{UO}_{2}^{+}$in the ion trap for a period of 1 second without imposed collisional activation. Because only the ion at $\mathrm{m} / \mathrm{z} 270$ was isolated for storage in the ion trap, the $\mathrm{m} / \mathrm{z} 288$ peak observed in Figure 4 is an $\mathrm{H}_{2} \mathrm{O}$ adduct to $\mathrm{m} / z 270$ formed by an association reaction in the gas phase. However, the intensity of $\mathrm{m} / \mathrm{z} 288(<5 \%$ relative to $\mathrm{m} / \mathrm{z} 270)$ is vastly lower than the peak at the same $\mathrm{m} / \mathrm{z}$ that was an apparent product ion generated by the CID of

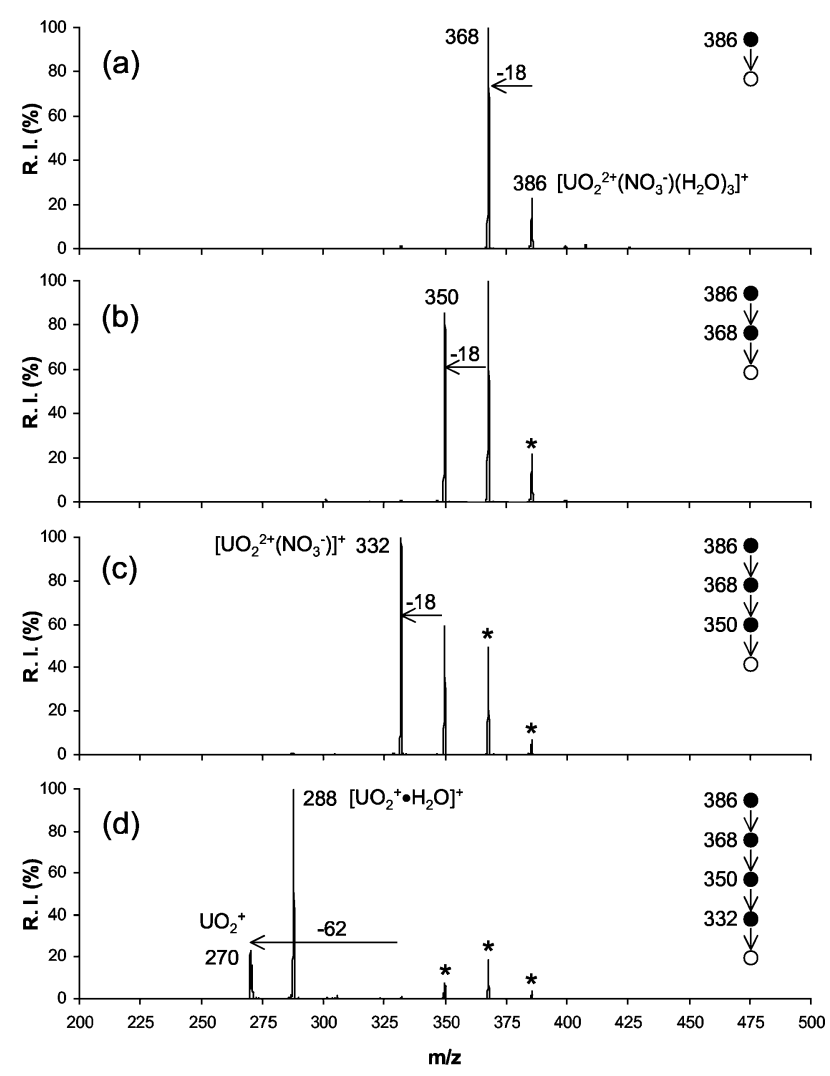

Figure 3. Multiple stage CID spectra initiated with the dissociation of the $\left[\mathrm{UO}_{2}^{2+}\left(\mathrm{NO}_{3}^{-}\right)\left(\mathrm{H}_{2} \mathrm{O}\right)_{3}\right]^{+}$complex ion derived from $\mathrm{UO}_{2}\left(\mathrm{NO}_{3}\right)_{2}$ dissolved in deionized $\mathrm{H}_{2} \mathrm{O}$. Peaks marked with an asterisk indicate $\mathrm{H}_{2} \mathrm{O}$ adducts formed from reaction of the CID products with adventitious water in the IT-MS.

$\left[\mathrm{UO}_{2}^{2+}\left(\mathrm{NO}_{3}^{-}\right)\right]$shown in Figure $3 \mathrm{~d}$. The activation time used to dissociate $\left[\mathrm{UO}_{2}^{2+}\left(\mathrm{NO}_{3}^{-}\right)\right]$in the $\mathrm{MS}^{\mathrm{n}}$ experiments was $30 \mathrm{msec}$, considerably less than the isolation and storage time used to produce the $\mathrm{H}_{2} \mathrm{O}$ adduct to $\mathrm{UO}_{2}^{+}$ observed in Figure 4. Therefore, it is unlikely that $\mathrm{m} / \mathrm{z}$ 288 observed following CID of $\left[\mathrm{UO}_{2}^{2+}\left(\mathrm{NO}_{3}^{-}\right)\right]$results from a slow, serial addition of $\mathrm{H}_{2} \mathrm{O}$ to the $\mathrm{m} / \mathrm{z} 270\left(\mathrm{UO}_{2}^{+}\right)$ product ion. This conclusion is supported by a recent

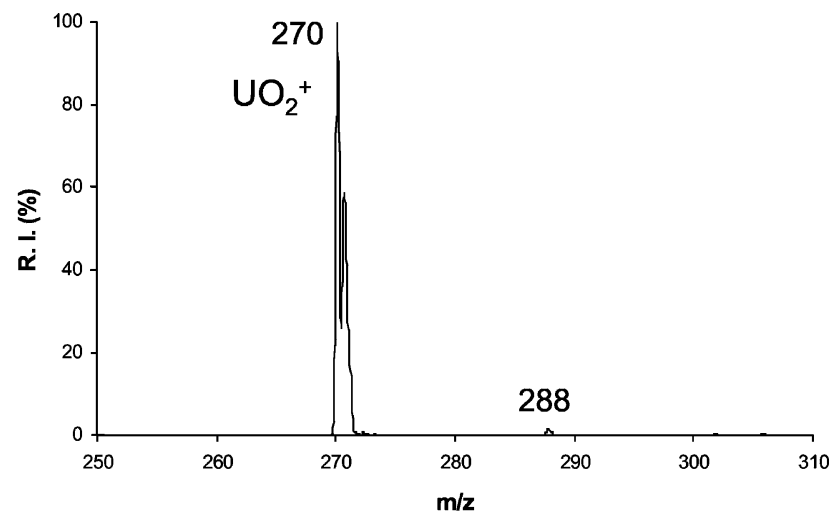

Figure 4. Mass spectrum generated by the isolation and storage of $\mathrm{UO}_{2}^{+}(\mathrm{m} / \mathrm{z} 270)$ in the ion trap for $1 \mathrm{~s}$. The peak at $\mathrm{m} / \mathrm{z} 288$ is an $\mathrm{H}_{2} \mathrm{O}$ adduct formed by an association reaction in the ion trap during the storage period. 
investigation that demonstrated slow hydration rates for the reduced uranyl ion produced by ion induced sputtering of solid $\mathrm{UO}_{3}$ [42]. We propose instead that the product may be generated via the reaction:

$$
\begin{aligned}
& {\left[\mathrm{UO}_{2}^{2+}\left(\mathrm{NO}_{3}{ }^{-}\right)\right]+\mathrm{H}_{2} \mathrm{O} \rightarrow\left[\mathrm{UO}_{2}^{2+}\left(\mathrm{NO}_{3}{ }^{-}\right)\left(\mathrm{H}_{2} \mathrm{O}\right)\right]^{*} \rightarrow} \\
& {\left[\mathrm{UO}_{2}^{+}\left(\mathrm{H}_{2} \mathrm{O}\right)\right]+\mathrm{NO}_{3}{ }^{\circ}}
\end{aligned}
$$

in which an energetic collision with $\mathrm{H}_{2} \mathrm{O}$ in the ion trap mass spectrometer causes the formation of an activated ternary complex, rapidly followed by the reductive elimination of an $\mathrm{NO}_{3}$ radical (with electron transfer to the uranyl ion) to leave the hydrated, reduced uranyl ion. Noting again the recent experiments that have demonstrated activating collisions between precursor ions and small molecules such as $\mathrm{N}_{2}$ and $\mathrm{H}_{2} \mathrm{O}$ (He bath gas contaminants) [50], such a process is plausible. The presence of numerous, abundant $\mathrm{H}_{2} \mathrm{O}$ adducts in the $\mathrm{MS}^{\mathrm{n}}$ experiments show that significant levels of $\mathrm{H}_{2} \mathrm{O}$ are present within the $\mathrm{He}$ bath gas within the ion trap (Figures 2 and 3). In addition, isolation of the species at $\mathrm{m} / \mathrm{z} 332,\left[\mathrm{UO}_{2}^{2+}\left(\mathrm{NO}_{3}^{-}\right)\right]$, followed by storage in the ion trap for 1 second produced an intense hydrated complex (spectrum not shown), which supports the proposition that an activated reactive complex might also be formed during the CID experiment. As noted earlier, the formation of the $\mathrm{H}_{2} \mathrm{O}$ adduct to $\mathrm{UO}_{2}^{+}$was also observed following the CID of $\left[\mathrm{UO}_{2}^{2+}\left(\mathrm{MeO}^{-}\right)\right]^{+}$and of $\left[\mathrm{UO}_{2}^{2+}\left(\mathrm{EtO}^{-}\right)\right]^{+}$species; these adducts likely arise via a similar process.

$\mathrm{MS}^{\mathrm{n}}$ spectra for $\left[\mathrm{UO}_{2}^{2+}\left(\mathrm{OH}^{-}\right)\left(\mathrm{H}_{2} \mathrm{O}\right)_{3}\right]^{+}$, at $\mathrm{m} / \mathrm{z} 341$, derived from ESI of the $\mathrm{UO}_{2}\left(\mathrm{NO}_{3}\right)_{2}$ solution in pure deionized $\mathrm{H}_{2} \mathrm{O}$ are shown in Figure 5. As with the nitrate-bearing ion at $\mathrm{m} / \mathrm{z} 386$, the MS/MS, $\mathrm{MS}^{3}$, and $\mathrm{MS}^{4}$ CID stages caused the successive elimination of coordinating $\mathrm{H}_{2} \mathrm{O}$ molecules; the ultimate end product in this case was $\left[\mathrm{UO}_{2}^{2+}\left(\mathrm{OH}^{-}\right)\right]^{+}$at $m / z 287$. Subsequent CID of this ion caused the elimination of $17 \mathrm{u}$, attributed to a hydroxyl radical, to generate the reduced uranyl ion, $\mathrm{UO}_{2}^{+}$at $\mathrm{m} / \mathrm{z} 270$. Unlike the CID of the species at $\mathrm{m} / \mathrm{z}$ 301 and 332 discussed above, the dissociation of the peak at $\mathrm{m} / \mathrm{z} 287$ did not result in the formation of the hydrated, reduced uranyl ion at $\mathrm{m} / \mathrm{z} 288$. This suggests that if a mechanism for the production of the peak at $\mathrm{m} / \mathrm{z} 288$ proceeds as proposed above, the formation of the activated complex may be assisted or stabilized by the presence of the nitrate or alkoxide anions in the $\mathrm{UO}_{2}^{2+}$-anion pair, but not by hydroxide.

The CID of the higher mass ions at $m / z 762$ and 822 observed following ESI of uranyl nitrate in $\mathrm{H}_{2} \mathrm{O}$ / $\mathrm{MeOH}$, and similar species generated from the other alcohols, was also examined. Regardless of the alcohol, MS/MS and MS $^{3}$ caused the elimination of alcohol molecules. For the complex ion at $\mathrm{m} / \mathrm{z} 822$ generated from $\mathrm{MeOH}$, and similar complexes containing the other alcohols, CID at the $\mathrm{MS}^{3}$ and $\mathrm{MS}^{4}$ stages generated a product ion via the elimination of a stoichiometric $\mathrm{UO}_{2}\left(\mathrm{NO}_{3}\right)_{2}$ unit. The prominence of this CID path-

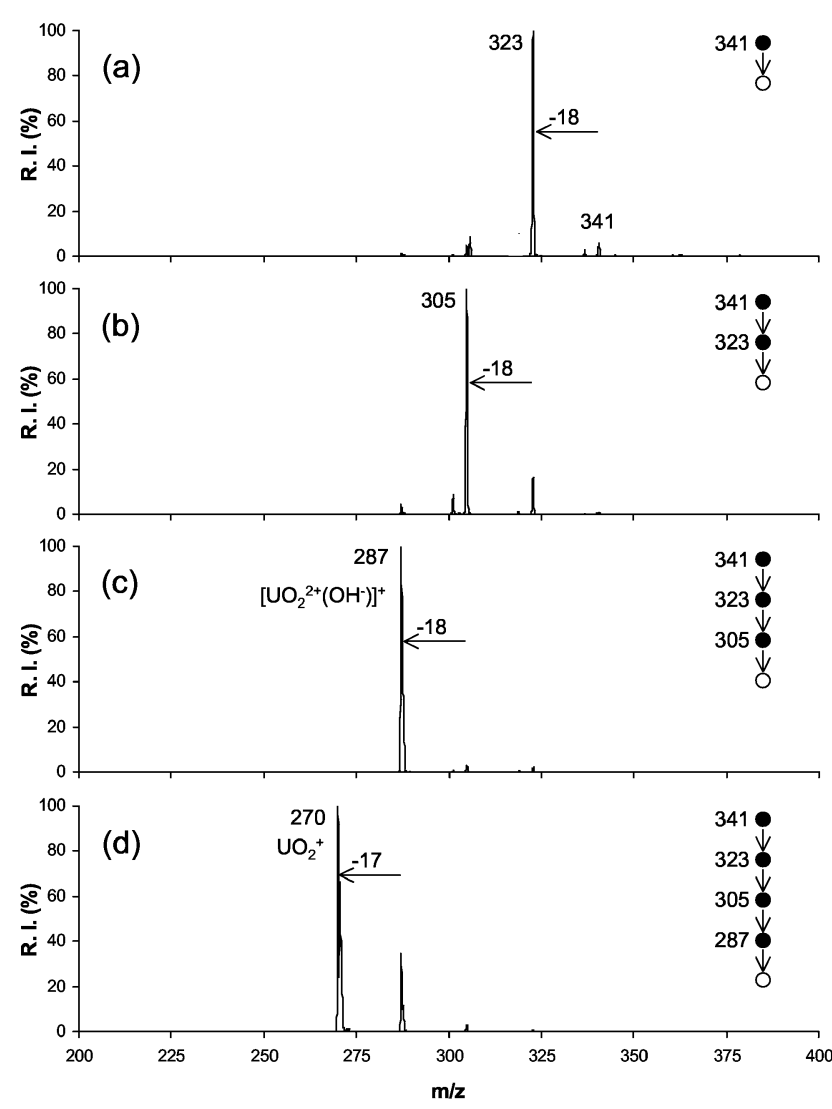

Figure 5. Multiple stage CID spectra initiated with the dissociation of the $\left[\mathrm{UO}_{2}^{2+}\left(\mathrm{OH}^{-}\right)\left(\mathrm{H}_{2} \mathrm{O}\right)_{3}\right]^{+}$complex ion derived from $\mathrm{UO}_{2}\left(\mathrm{NO}_{3}\right)_{2}$ dissolved in deionized $\mathrm{H}_{2} \mathrm{O}$.

way increased with the size of the alcohol molecule within the complex. The CID product ions generated from the higher-mass complex ions showed a high tendency to hydrate in the ion trap, and at high $\mathrm{MS}^{\mathrm{n}}$ stages (i.e., $>\mathrm{MS}^{3}$ ) the product ion mass spectra were dominated by $\mathrm{H}_{2} \mathrm{O}$ adducts. In many cases, the intensities of CID product ions were only $1-5 \%$ relative to their associated $\mathrm{H}_{2} \mathrm{O}$ adducts. The diminished product ion intensities precluded the investigation of subsequent CID stages, and the generation of complete $\mathrm{MS}^{\mathrm{n}}$ schemes for the higher mass complexes was not possible.

\section{Conclusions}

To the best of our knowledge, this is the first demonstration that ESI can be used to generate gas-phase complexes composed of the $\mathrm{UO}_{2}^{2+}$, hydroxide or nitrate, and coordinating $\mathrm{H}_{2} \mathrm{O}$ and alcohol molecules: species relevant to the study of the interaction between uranyl complexes and solvent. The combination of ESI and IT-MS should therefore be a useful tool for characterizing the intrinsic chemistry of the coordinated uranyl ion. For species in which the complex contained the nitrate anion and coordinating alcohol molecules, multiple CID stages caused the elimination of two alcohol molecules and nitric acid to leave an ion pair composed 
of the uranyl ion and an alkoxide anion. ESI of a solution containing uranyl nitrate in deionized $\mathrm{H}_{2} \mathrm{O}$ resulted in the production of complexes containing the uranyl ion, either nitrate or hydroxide, and coordinating $\mathrm{H}_{2} \mathrm{O}$ molecules. Multiple stage CID of the species incorporating hydroxide generated $\left[\mathrm{UO}_{2}^{2+}\left(\mathrm{OH}^{-}\right)\right]$via the elimination of the coordinating $\mathrm{H}_{2} \mathrm{O}$ molecules, and ultimately the reduced uranyl ion. Multiple-stage CID of the species incorporating nitrate instead generated an apparent hydrated, reduced uranyl ion, $\mathrm{UO}_{2}^{+} \cdot \mathrm{H}_{2} \mathrm{O}$, which we propose is the result of the formation of an activated, ternary complex including an $\mathrm{H}_{2} \mathrm{O}$ molecule during the final dissociation reaction.

Regardless of the coordinating anion, ESI produced gas-phase uranyl complexes that contained three solvent molecules, whether alcohol or $\mathrm{H}_{2} \mathrm{O}$. Work by Vachet and Callahan [14] has suggested that the nitrate anion, within gas-phase transition metal complexes, is primarily a bidentate ligand. The acceptance of three additional ligands by the uranyl-nitrate ion pair is consistent with a hypothesis that ESI produces a gasphase complex with a pentagonal bipyramidal conformation reminiscent of the structure of uranyl complexes in the solution phase [5-11]. The fact that the uranylhydroxide containing complex ion, as generated by ESI, also incorporated a maximum of 3 additional $\mathrm{H}_{2} \mathrm{O}$ ligands is therefore interesting. The hydroxide anion is a monodentate ligand, and the acceptance of $3 \mathrm{H}_{2} \mathrm{O}$ ligands to produce the peak at $m / z 341$ suggests that the gas-phase complex adopts an octahedral conformation (i.e., with three $\mathrm{H}_{2} \mathrm{O}$ ligands joining an hydroxide ligand in the equatorial coordination plane). Isolation and storage of the peak at $m / z 341$ for $10 \mathrm{~s}$ failed to produce a complex with 1 additional $\mathrm{H}_{2} \mathrm{O}$ molecule, demonstrating that the complex is highly resistant to the addition of a fifth equatorial ligand. The behavior in the gas phase is therefore in stark contrast to the structure of uranyl complexes in solution.

Currently we are in the process of investigating the intrinsic hydration reaction rates of the uranyl cationanion pairs to assess the discrepancies observed between the species generated here by ESI and those from solution phase investigations. In addition, we have also begun an investigation of the most probable gas-phase conformations of the coordinated uranyl ions using ab-initio calculations, which should shed considerable light on the thermodynamic factors that guide the stability of these complexes.

\section{Acknowledgments}

MVS acknowledges support for this work by a grant from the National Science Foundation (CAREER-0239800), a First Award from the Kansas Technology Enterprise Corporation/Kansas NSF EPSCoR program, and a subcontract from the U.S. Department of Energy through the INEEL Institute. DH acknowledges the support of the Wichita State University Research Sites for Educators in Chemistry program sponsored by the National Science Foundation. GSG and GLG acknowledge support by the U.S. Department of Energy, Environmental Systems Research Program, under contract DE-AC-07-99ID13727. Funds for the purchase of the LCQ-Deca instrument were provided by the Kansas NSF EPSCoR program and the Wichita State University College of Liberal Arts and Sciences.

\section{References}

1. Weigel, F. Uranium. In The Chemistry of the Actinide Elements, Katz, J. J.; Morss, L. R.; Seaborg, G. T., Eds.; Chapman and Hall: London, 1986 ; p 169.

2. Greenwood, N. N.; Earnshaw, A. Chemistry of the Elements. Butterworth Heinemann: Oxford, Great Britain, 1997, pp $1260-1262$.

3. Murphy, W. M.; Shock, E. L. Environmental Aqueous Geochemistry of Actinides. Uranium: Mineralogy, Geochemistry, and the Environment; In Burns, P. C.; Finch, R., Eds.; Mineralogical Society of America: Washington, D.C., 1999; p 221.

4. Brookins, D. G. Geochemical Aspects of Radioactive Waste Disposal. Springer-Verlag: New York, 1984, pp 27-30, 203-231.

5. Evans, H. T. Science 1963, 141, 154.

6. Thompson, H. A.; Brown, G. E.; Parks, G. A. Am. Mineral 1997, 82, 483-496.

7. Aberg, M.; Ferri, D.; Glaser, J.; Grenthe, I. Inorg. Chem. 1983, 22, 3986-3989.

8. Allen, P. G.; Bucher, J. J.; Shuh, D. K.; Edelstein, N. M.; Reich, T. Inorg. Chem. 1997, 36, 4676-4683.

9. Dent, A. J.; Ramsay, J. D. F.; Swanton, S. W. J. Colloid Interface Sci. 1992, 150, 45-60.

10. Nguyen-Trung, C.; Begun, G. M.; Palmer, D. A. Inorg. Chem. 1992, 31, 5280.

11. Nguyen-Trung, C.; Palmer, D. A.; Begun, G. M.; Peiffert, C.; Mesmer, R. E. J. Solution Chem. 2000, 29, 101-129.

12. Vachet, R. W.; Hartman, J. A. R.; Callahan, J. H. J. Mass Spectrom. 1998, 33, 1209-1225.

13. Hartman, J. R.; Vachet, R. W.; Callahan, J. H. Inorg. Chim. Acta 2000, 297, 79-87.

14. Vachet, R. W.; Callahan, J. H. J. Mass Spectrom. 2000, 35, 311-320.

15. Vachet, R. W.; Hartman, J. R.; Gertner, J. W.; Callahan, J. H. Int. J. Mass Spectrom. 2001, 204, 101.

16. Combariza, M. Y.; Vachet, R. W. J. Am. Soc. Mass Spectrom. 2002, 13, 813-825.

17. Wu, H. F.; Brodbelt, J. S. Inorg. Chem. 1995, 34, 615-621.

18. Scott, J. R.; Groenewold, G. S.; Gianotto, A. K.; Benson, M. T.; Wright, J. B. J. Phys. Chem. A 2000, 104, 7079-7090.

19. Groenewold, G. S.; Hodges, B. D. M.; Scott, J. R.; Gianotto, A. K.; Appelhans, A. D.; Kessinger, G. F.; Wright, J. B. J. Phys. Chem. A 2001, 105, 4059-4064.

20. Groenewold, G. S.; Scott, J. R.; Gianotto, A. K.; Hodges, B. D. M.; Kessinger, G. F.; Benson, M. T.; Wright, J. B. J. Phys. Chem. A 2001, 105, 9681-9688.

21. Innorta, G.; Torroni, S.; Foffani, A.; Pontoni, L. J. Mass Spectrom. 1995, 30, 1633-1635.

22. Operti, L.; Splendore, M.; Vaglio, G. A.; Franklin, A. M.; Todd, J. F. J. Int. J. Mass Spectrom. Ion Processes 1994, 136, 25-33.

23. Perera, B. A.; Ince, M. P.; Talaty, E. R.; Van Stipdonk, M. J. Rapid Commun. Mass Spectrom. 2001, 15, 615-622.

24. Perera, B. A.; Gallardo, A. L.; Barr, J. M.; Tekarli, S. M.; Anbalagan, V; Talaty, E. R.; Van Stipdonk, M. J. J. Mass Spectrom. 2002, 37, 401.

25. Talaty, E. R.; Perera, B. A.; Gallardo, A. L.; Barr, J. M.; Van Stipdonk, M. J. J. Phys. Chem. A 2001, 105, 8059-8068.

26. Gibson, J. K. Int. J. Mass Spectrom. Ion Processes 2002, 213, 1.

27. Gibson, J. K. Organometallics 1997, 16, 4214-4222.

28. Gibson, J. K. J. Am. Chem. Soc. 1998, 120, 2633-2640.

29. Gibson, J. K. J. Mass Spectrom. 1999, 34, 1166-1177. 
30. Heinemann, C.; Cornehl, H. H.; Schwarz, H. J. Organomet. Chem. 1995, 501, 201-209.

31. Armentrout, P. B.; Beauchamp, J. L. Chem. Phys. 1980, 50, 27-36.

32. Jackson, G. P.; King, F. L.; Goeringer, D. E.; Duckworth, D. C. J. Phys. Chem. A 2002, 106, 7788-7794.

33. Cornehl, H. H.; Heinemann, C.; Marcalo, J.; deMatos, A. P.; Schwarz, H. Angew. Chem. Int. Ed. Engl. 1996, 35, 891-894.

34. Gibson, J. K. J. Mass Spectrom. 2001, 36, 284-293.

35. Moulin, C.; Charron, N.; Plancque, G.; Virelizier, H. Appl. Spectrosc. 2000, 54, 843-848.

36. Wu, Q. C.; Cheng, X.; Hofstadler, S. A.; Smith, R. D. J. Mass Spectrom. 1996, 31, 669-675.

37. Dion, H. M.; Ackerman, L. K.; Hill, H. H. Talanta 2002, 57, 1161-1171.

38. Dion, H. M. A.; Ackerman, L. K.; Hill, H. H. Int. J. Ion Mobil. Spectrom. 2001, 4, 31-33.

39. McClellan, J. E. Murphy, J. P., III;; Mulholland, J. J.; Yost, R. A. Anal. Chem. 2002, 74, 402-412.

40. Wells, J. M.; Plass, W. R.; Patterson, G. E.; Zheng, O. Y.; Badman, E. R.; Cooks, R. G. Anal. Chem. 1999, 71, 3405-3415.
41. Peng, Y.; Plass, W. R.; Cooks, R. G. J. Am. Soc. Mass Spectrom. 2002, 13, 623-629.

42. Gresham, G. L.; Gianotto, A. K.; Harrington, P. B.; Cao, L.; Scott, J. R.; Olson, J. E.; Appelhans, A. D.; Van Stipdonk, M. J.; Groenewold, G. S.; unpublished.

43. Gresham, G. L.; Groenewold, G. S.; Hanna, D.; Anbalagan, V.; Van Stipdonk, M. J.; in press.

44. Berg, J. B. C.; Clark, D. L.; Huffman, J. C.; Morris, D. E.; Sattelberger, A. P.; Streib, W. E.; Van der Sluys, W. G.; Watkin, J. G. J. Am. Chem. Soc. 1992, 114, 10811.

45. Van der Sluys, W. G. S.; Sattelberger, A. P. Chem. Rev. 1990, 90, 1027.

46. Avrens, L. R. B.; Barnhart, D. M.; Burns, C. J.; McKee, S. D.; Smith, W. H. Inorg. Chem. 1994, 33, 4245.

47. Akibo-Betts, G.; Barran, P. E.; Puskar, L.; Duncombe, B.; Cox, H.; Stace, A. J. J. Am. Chem. Soc. 2002, 124, 9257-9264.

48. Brauman, J. I. B.; Blair, L. K. J. Am. Chem. Soc. 1968, 90, 6561.

49. Brauman, J. I. B.; Blair, L. K. J. Am. Chem. Soc. 1970, 92, 5986.

50. Catinella, S.; Pelizzi, N.; Barboso, S.; Favretto, D.; Seraglia, R.; Traldi, P. Rapid Commun. Mass Spectrom. 2002, 16, 1897-1902.

51. Goeringer, D. E.; Duckworth, D. C.; McLuckey, S. A. J. Phys. Chem. A 2001, 105, 1882-1889. 